\title{
Pemasangan Reklame di Koridor Jl. Kertajaya Ditinjau Dari Aspek Hukum
}

\author{
Suprapti, Niken Prasetyawati, Usman Arief, dan Heru Purwadio
}

\begin{abstract}
Abstrak
Setelah terbit Peraturan Daerah Kota Surabaya Nomor 10 Tahun 2009 tentang Perubahan Atas Peraturan Daerah Kota Surabaya Nomor 8 Tahun 2006 Tentang Penyelenggaraan Reklame dan Pajak Reklame, serta Peraturan Walikota Surabaya Nomor 79 Tahun 2012 tentang Tata Cara Penyelenggaraan Reklame, pemasangan reklame di koridor utama Kota Surabaya tampak lebih teratur. Namun demikian masih dijumpai penempatan reklame yang tidak sesuai dengan ketentuan peraturan yang berlaku. Salah satunya adalah pemasangan reklame di sepanjang koridor J. Kertajaya mulai perempatan Jl. Menur sampai viaduct Gubeng Terowongan. Masalah yang diidentifikasikan adalah, penempatan reklame yang melebihi batas persil; melebihi ketinggian bangunan reklame tersebut berada; reklame yang proporsinya lebih besar dibandingkan bidang reklame tersebut berada; jarak antara penempatan reklame yang satu dan reklame lainnya sangat berdekatan; dan reklame pada kaki viaduct kereta api.

Studi ini bertujuan untuk menemukenali penyimpangan penempatan reklame, yang dilakukan melalui evaluasi kondisi faktual pemasangan reklame di sepanjang koridor Jl. Kertajaya terhadap aspek hukum; dalam hal ini terhadap Peraturan Daerah Kota Surabaya Nomor 10 Tahun 2009 tentang Penyelenggaraan Reklame; Peraturan Walikota Surabaya Nomor 79 Tahun 2012 tentang Tata Cara Penyelenggaraan Reklame; dan Peraturan Pemerintah No. 56 Tahun 2009 tentang Penyelenggaraan Perkeretaapian. Studi ini masuk dalam kategori doctrinal research melalui pendekatan kasus (Marzuki; 2005) dengan cara mengevaluasi kondisi lapangan terhadap ketentuan undang-undang, peraturan pemerintah dan peraturan lain yang berlaku.

Berdasarkan hasil studi ditunjukkan bahwa (1) terdapat tujuh reklame billboard di atas tiang yang melebihi Garis Sempadan Pagar atau batas persil; (2) terdapat satu reklame videotron yang berada di dalam Rumija Kereta Api; (3) terdapat dua reklame pada bangunan yang melebihi Garis Sempadan Bangunan; dan (5) terdapat delapan reklame billboard yang dipasang melebihi tinggi bangunan; terdapat satu reklame tanpa materi; terdapat empat spot yang jarak penempatan reklamenya berdekatan; dan satu reklame pada pos polisi lalu lintas yang melebihi luas bidang reklame.
\end{abstract}

Kata kunci : pemasangan, reklame, aspek hukum

Setelah terbitnya Peraturan Daerah Kota Surabaya Nomor 10 Tahun 2009 tentang Perubahan Atas Peraturan Daerah Kota Surabaya Nomor 8 Tahun 2006 Tentang Penyelenggaraan Reklame dan Pajak Reklame, yang ditindaklanjuti dengan Peraturan Walikota Surabaya Nomor 79 Tahun 2012 tentang Tata Cara Penyelenggaraan Reklame, pemasangan reklame di jalan-jalan utama Kota Surabaya 
tampak lebih teratur. Namun demikian masih juga terdapat permasalahan di lapangan. Salah satunya adalah pemasangan reklame di sepanjang kiri dan kanan Jl. Kertajaya (koridor Jl. Kertajaya), antara lain menempatan reklame yang melebihi Garis Sempadan Pagar; melebihi tinggi bangunan tempat reklame tersebut berada. Selain itu, proporsi reklame lebih besar dibandingkan bidang reklame tersebut berada; jarak antara reklame yang satu dan reklame lain sangat berdekatan; reklame pada kaki viaduct kereta api; reklame yang dipasang tanpa muatan materi atau reklame kosong.

Permasalahan-permasalahan pemasangan reklame tersebut mengindikasikan masih adanya ketidaksesuaian atau penyimpangan pemasangan reklame di koridor Jl. Kertajaya terhadap peraturan yang berlaku. Hal ini adalah ketentuan penempatan reklame pada lokasi persil persil dan bukan persil. Peraturan yang mengatur tentang pemasangan reklame di wilayah studi adalah Peraturan Daerah Kota Surabaya Nomor 10 Tahun 2009 Tentang Perubahan Atas Peraturan Daerah Kota Surabaya Nomor 8 Tahun 2006 Tentang Penyelenggaraan Reklame dan Pajak Reklame; Peraturan Walikota Surabaya Nomor 79 Tahun 2012 tentang Tata Cara Penyelenggaraan Reklame; dan Peraturan Pemerintah Nomor 56 Tahun 2009 Tentang Penyelenggaraan Perkeretaapian.

Berkaitan dengan permasalahan yang diidentifikasikan, studi ini bertujuan untuk menemukenali lebih lanjut ketidaksesuaian dan penyimpangan penempatan reklame di wilayah studi ditinjau dari peraturan yang berlaku. Ketidaksesuaian atau penyimpangan penempatan reklame mudah diididentifikasi karena posisinya terhadap batas persil, wajah bangunan, dan bantaran rel kereta api mudah dilihat secara visual.

Lingkup studi ini mencakup dua hal, yaitu lingkup wilayah dan lingkup substansi. Ditinjau dari cakupan wilayahnya, studi ini mencakup sepanjang kiri kanan J1. Kertajaya atau koridor J1. Kertajaya baik lokasi persil maupun bukan persil. Reklame pada lokasi persil adalah reklame yang ditempatkan di dalam perpetakan bangunan, mencakup reklame yang ditempatkan pada bangunan dan daerah sempadan bangunan; sedangkan reklame pada lokasi bukan persil 
mencakup reklame yang berada pada Ruang Milik Jalan, dan bantaran rel Kereta Api (Peraturan Daerah Kota Surabaya Nomor 10 Tahun 2009; Peraturan Walikota Surabaya Nomor 79 Tahun 2012).

Ditinjau dari substansinya, studi ini membatasi kajiannya pada jenis reklame tetap yang berada pada bangunan dan ruang luar, yang terdiri dari reklame papan atau billboard dan videotron (Peraturan Daerah Kota Surabaya Nomor 10 Tahun 2009; Peraturan Walikota Surabaya Nomor 79 Tahun 2012).

Kajian reklame pada umumnya mencakup jenis, penempatan, dimensi, struktur, estetika, dan pesan atau muatan isi reklame (Bapeprov Jawa Timur; 2009). Studi ini membatasi kajiannya pada penempatan reklame.

\section{Pengertian}

Pengertian-pengertian yang relevan dengan studi ini merujuk pada Peraturan Daerah Kota Surabaya No. 10 Tahun 2009 tentang Penyelenggaraan Reklame.

1. Pasal 1, butir (10)

Reklame adalah benda, alat, perbuatan atau media yang bentuk atau corak ragamnya dirancang untuk tujuan komersial, memperkenalkan, menganjurkan, mempromosikan atau untuk menarik perhatian umum terhadap barang, jasa, orang atau badan yang dapat dilihat, dibaca, didengar, dirasakan, dan/atau dinikmati oleh umum.

2. Pasal 1, butir (11)

Reklame megatron adalah reklame yang bersifat tetap (tidak dapat dipindahkan), menggunakan layar monitor maupun tidak, berupa gambar dan/atau tulisan yang dapat berubah-ubah, terprogram dan menggunakan tenaga listrik. Termasuk di dalamnya adalah videotron dan electronic display.

3. Pasal 1, butir (12)

Reklame papan atau billboard adalah reklame yang bersifat tetap (tidak dapat dipindahkan) terbuat dari papan, kayu, seng, tinplate, collibrite, vinyl, aluminium, fiberglass, kaca, batu, tembok atau beton, logam atau bahan lain yang sejenis, dipasang pada tempat yang disediakan (berdiri sendiri) atau 
digantung atau ditempel atau dibuat pada bangunan tembok, dinding, pagar, tiang, dan sebagainya baik bersinar, disinari maupun yang tidak bersinar.

Ditinjau dari lokasinya, reklame dibedakan atas reklame di lokasi persil dan bukan persil.

1. Pasal 1, butir (35)

Lokasi persil adalah suatu perpetakan tanah yang terdapat dalam lingkup rencana kota atau rencana perluasan kota atau jika sebagian masih belum ditetapkan rencana perpetakannya, namun menurut pertimbangan Pemerintah Daerah dapat digunakan untuk mendirikan sesuatu bangunan.

2. Pasal 1, butir (36)

Lokasi bukan persil adalah semua ruang di luar persil, di dalam wilayah Daerah, termasik keseluruhan Ruang Milik Jalan baik milik pemerintah maupun penyelenggara Jalan Tol, Daerah Manfaat Sungai dan bantaran rel kereta api serta prasarana lingkungan yang oleh perusahaan pembangunan perumahan belum diserahkan kepada Pemerintah Daerah.

\section{Peraturan yang Berkaitan dengan Pemasangan Reklame di Koridor Jl. Kertajaya \\ Peraturan yang digunakan untuk mengevaluasi ketidaksesuaian atau penyimpangan penempatan reklame di Koridor Jl. Kertajaya adalah:}

\section{Peraturan Pemerintah No. 56 Tahun 2009 tentang Penyelenggaraan Perkeretaapian}

Wilayah studi berbatasan langsung dengan jalur kereta api karena perlu mempertim-bangkan ketentuan yang bertautan dengan penempatan reklame yang berdekatan dengan jalur kereta api. Ketentuan dalam Peraturan Pemerintah No. 56 Tahun 2009 yang bertautan dengan cakupan studi ini adalah:

a. Pasal 58 ayat (1)

Batas Rumija Kereta Api untuk jalan rel yang terletak pada permukaan tanah diukur dari batas paling luar sisi kiri dan kanan Rumaja Kereta Api, lebarnya paling sedikit 6 meter.

b. Pasal 58 ayat (4) 
Dalam hal rel yang terletak di atas permukaan tanah berhimpit dengan jalan, batas Rumija berhimpit dengan Rumaja.

c. Pasal 59 ayat (1)

Rumija Kereta Api dapat digunakan untuk keperluan lain atas izin pemilik prasarana perkeretaapian dengan ketentuan tidak membahayakan konstruksi jalan rel, fasilitas operasi kereta api, dan perjalanan kereta api.

d. Pasal 59 ayat (2)

Kegiatan lain yang dimaksud adalah (a) pipa gas, (b) pipa minyak, (c) pipa air, (d) kabel telepon, (e) kabel listrik, atau (f) menara telekomunikasi.

\section{Peraturan Daerah Kota Surabaya No. 10 Tahun 2009 tentang Penyelenggaraan Reklame}

Ketentuan yang relevan dengan reklame di wilayah studi adalah :

a. Pasal 16:

Setiap orang atau badan dilarang menyelenggarakan reklame:

(a) Di lokasi persil kantor instansi pemerintah, pemerintah provinsi atau pemerintah daerah, yang akan ditetapkan lebih lanjut dengan Peraturan Kepala Daerah.

(b) Pada bangunan atau tempat-tempat lain yang diatur dengan Peraturan Kepala Daerah.

(c) Pada titik-titik yang tidak sesuai dengan ketentuan Kawasan Penataan Reklame yang diatur dengan Peraturan Kepala Daerah.

b. Pasal 19 ayat (1) :

Penyelenggaraan reklame di lokasi bukan persil harus memenuhi ketentuan:

(c) Luas bidang reklame disesuaikan dengan keadaan dan estetika kota yang akandiatur lebih lanjut dengan Peraturan Kepala Daerah.

(d) Tidak menutup/mengganggu pandangan perlintasan sebidang kereta api.

(e) Jarak dari as rel kereta api sampai bidang konstruksi reklame terdekat harusmendapat rekomendasi dari PT. Kereta Api Indonesia. 
(g) Tidak mengganggu fungsi atau merusak sarana dan prasarana kota serta tidak mengganggu pemeliharaannya.

(h) Kaki konstruksi tidak boleh berada di saluran air, sungai atau badan jalan.

c. Pasal 20

Penyelenggaraan reklame di lokasi persil harus memenuhi ketentuan:

(c) Bidang reklame tidak boleh melebihi Garis Sempadan Pagar (GSP).

(d) Penyelenggaraan reklame menempel pada bangunan dapat dipasang dengan ketentuan bidang reklame tidak melebihi Garis Sempadan Bangunan (GSB).

(e) Penyelenggaraan reklame di atas bangunan, diselenggarakan dengan ketentuan bidang reklame tidak boleh melebihi bidang atap tempat reklame tersebut.

d. Pasal 29

Bangunan konstruksi reklame dilarang kosong tanpa materi.

\section{Peraturan Walikota Surabaya Nomor 79 Tahun 2012 tentang Tata Cara Penyelenggaraan Reklame}

Ketentuan yang diatur dalam Peraturan Walikota Surabaya Nomor 79 Tahun 2012 tentang Tata Cara Penyelenggaraan Reklame, yang relevan dengan lingkup studi ini, adalah:

a. Pasal 15 ayat (1)

Penyelenggaraan reklame di lokasi bukan persil dapat dilakukan pada lokasi bukan persil milik/dikuasai pemerintah daerah atau lokasi bukan persil yang meliputi seluruh Ruang Milik Jalan yang dimiliki/dikuasai pemerintah/pemerintah provinsi, penyelenggara jalan tol, daerah Manfaat Sungai dan bantaran rel kereta api, serta prasarana lingkungan yang oleh perusahaan pembangunan perumahan belum diserahkan kepada pemerintah daerah. 
b. Pasal 15 ayat (2)

Penyelenggaraan reklame di lokasi bukan persil hanya dapat dilakukan pada titik-titik lokasi yang telah ditentukan dalam kawasan penataan reklame kecuali pada lokasi bukan persil yang meliputi keseluruhan Ruang Milik Jalan yang dimiliki/dikuasai pemerintah/pemerintah provinsi, penyelenggara jalan tol dan daerah Manfaat Sungai dan bantaran rel kereta api serta prasarana lingkungan yang oleh perusahaan pembangunan perumahan belum diserahkan kepada pemerintah daerah, yang belum ditetapkan sebagai kawasan penataan reklame masih diperbolehkan diselenggarakan reklame dengan mengikuti ketentuan mengenai penyelenggaraan reklame di lokasi bukan persil pada kawasan penataan reklame.

c. Pasal 15 ayat (3)

Penyelenggaraan reklame di lokasi bukan persil hanya dapat dilakukan pada titik-titik lokasi yang telah ditentukan dalam kawasan penataan reklame.

d. Pasal 16 ayat (1)

Kawasan penataan reklame berlaku untuk penyelenggaraan reklame di lokasi persil dan lokasi bukan persil.

e. Pasal 17

Penyelenggaraan reklame di lokasi persil pada kawasan penataan reklame harus mengikuti ketentuan sebagai berikut :

(a) Pemasangan reklame pada tiang yang diselenggarakan pada jarak sampai dengan 6 meter dari garis pagar yang berbatasan dengan jalan hanya diperbolehkan dengan ketinggian tidak melebihi ketinggian bangunan persil tersebut, dan paling tinggi 9 meter dengan luas bidang reklame tidak boleh melebihi $24 \mathrm{~m} 2$.

(b) Pemasangan reklame pada tiang yang diselenggarakan pada jarak lebih dari 6 meter dari garis pagar yang berbatasan dengan jalan, hanya diperbolehkan dengan ketinggian tidak melebihi 20 meter, atau jika 
ketinggian bangunan lebih dari 20 meter, ketinggian reklame tidak boleh melebihi ketinggian bangunan di persil tersebut.

(c) Reklame yang diselenggarakan menempel pada bangunan tidak boleh melebihi bidang bangunan, dan ukuran tidak boleh melebihi $50 \%$ dari luas keseluruhan bidang bangunan yang dipergunakan untuk pemasangan reklame.

(e) Reklame yang dipasang pada tiang dan diselenggarakan di atas bangunan tidak boleh melebihi bidang atap bangunan dan harus diselenggarakan pada jarak lebih dari 6 meter dari garis pagar yang berbatasan dengan jalan.

(f) Dalam satu persil dapat diselenggarakan lebih dari satu titik reklame dengan ketentuan antara titik reklame satu dengan lainnya diselenggarakan secara sejajar dengan arah pandangan jalan atau reklame yang dipasang dengan cara menempel bangunan.

(g) Persil yang berada di persimpangan dan tikungan, pemasangan reklame pada tiang yang diselenggarakan pada jarak sampai 6 meter dari garis pagar yang berbatasan dengan jalan harus memperhatikan jarak antara bidang reklame satu dengan lainnya paling sedikit 10 meter.

f. Pasal 18

Ketentuan penyelenggaraan reklame pada kawasan penataan reklame bukan persil yang relevan dengan lingkup studi ini, adalah :

Pasal 18, butir (d)

Jika diselenggarakan di halte dan gardu jaga, maka:

1. Reklame diselenggarakan secara menempel pada bangunan.

2. Penempatan bidang reklame tidak boleh melebihi bidang bangunan dan ukuran tidak boleh melebihi 50\% dari luas keseluruhan bidang bangunan yang digunakan untuk pemasangan reklame.

Pasal 18, butir (f)

Jika diselenggarakan di bantaran rel kereta api, maka :

1. Ukuran bidang reklame tidak boleh melebihi $50 \mathrm{~m} 2$. 
2. Antara titik reklame dengan titik reklame lainnya dalam satu pandangan paling sedikit 50 meter.

\section{Pembahasan}

Pembahasan studi ini dilakukan dengan cara mengevaluasi kondisi empiris di lapangan terhadap ketentuan dalam Peraturan Pemerintah Nomor 56 Tahun 2009 Tentang Penyelenggaraan Perkeretaapian; Peraturan Daerah Kota Surabaya Nomor 10 Tahun 2009 Tentang Perubahan Atas Peraturan Daerah Kota Surabaya Nomor 8 Tahun 2006 Tentang Penyelenggaraan Reklame dan Pajak Reklame; dan Peraturan Walikota Surabaya Nomor 79 Tahun 2012 tentang Tata Cara Penyelenggaraan Reklame. Studi ini masuk kategori doctrinal research melalui pendekatan kasus sesuai dengan permasalahannya (Marzuki; 2005).

\section{Kajian terhadap Peraturan Pemerintah No. 56 Tahun 2009 tentang Penyelenggaraan Perkeretaapian.}

Dalam pasal 58 ayat (1) disebutkan bahwa batas Rumija Kereta Api untuk jalan rel diukur dari batas paling luar sisi kiri dan kanan Rumaja Kereta Api, lebarnya paling sedikit 6 meter. Posisi videotron berada di kaki viaduct dalam Rumaja yang berhimpit dengan Rumija Kereta Api. Di dalam pasal 59 ayat (1) disebutkan bahwa Rumaja dapat digunakan untuk keperluan lain atas izin pemilik prasarana perkeretaapian dengan ketentuan tidak membahayakan konstruksi jalan rel, fasilitas operasi kereta api, dan perjalanan kereta api. Kegiatan lain yang dimaksudkan adalah pipa gas, pipa minyak, pipa air, kabel telepon, kabel listrik, atau menara telekomunikasi. Kegiatan selain yang disebutkan diatur dengan peraturan menteri. Secara faktual obyek yang ditempatkan di dalam Rumija adalah videotron, bukan pipa gas, pipa minyak, pipa air, kabel telepon, kabel listrik atau menara telekomunikasi. Walaupun pemasangan videotron mendapat izin tertulis dari PT. (Persero) Kereta Api Indonesia DAOP VIII Surabaya, seharusnya di dalam Rumija Kereta Api terutama yang berada pada kaki viaduct, tidak digunakan untuk menempatkan 
reklame videotron, karena tidak termasuk salah satu infrastruktur yang diizinkan sesuai pasal 59 ayat (1) (lihat Foto 1).

\section{Kajian terhadap Peraturan Daerah Kota Surabaya No. 10 Tahun 2009 tentang Penyelenggaraan Reklame}

a. Dalam pasal 20 mengenai penyelenggaraan reklame pada lokasi persil, disebutkan bahwa:

(1) Bidang reklame tidak boleh melebihi Garis Sempadan Pagar (GSP).

Kondisi lapangan menunjukkan di wilayah studi terdapat 7 reklame billboard di J1. Kertajaya yang tidak sesuai dengan pasal 20 butir (b) Peraturan Daerah Kota Surabaya No. 10 Tahun 2009 tentang Penyelenggaraan Reklame, karena dipasang melebihi GSP atau melebihi batas persil.

Rinciannya 6 reklame terletak di sisi Utara Jl. Kertajaya, yaitu reklame Rumah Makan Halim, Reklame Happy Day Laundry, reklame toko, reklame Alfamart, Apotek Pemuda dan rokok Dun Hill; dan satu reklame di sisi Selatan Jl. Kertajaya, yaitu reklame Polaris (lihat Foto 2).

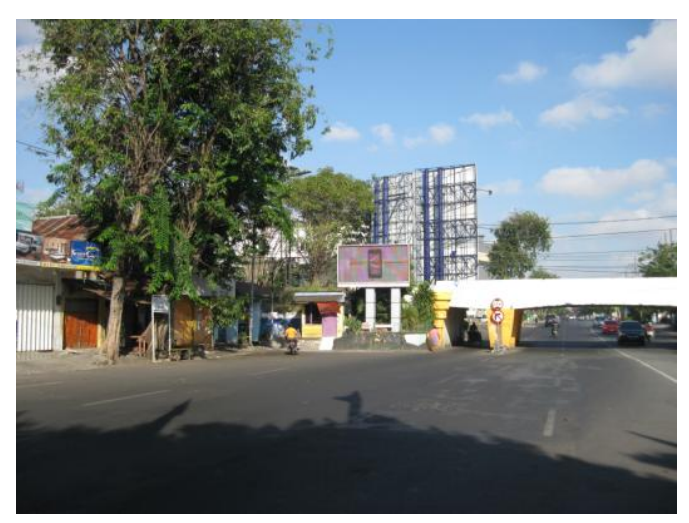

Foto 1

Videotron di kaki viaduct jalur kereta api.

Sumber : Survei lapangan; Agustus; 2013.

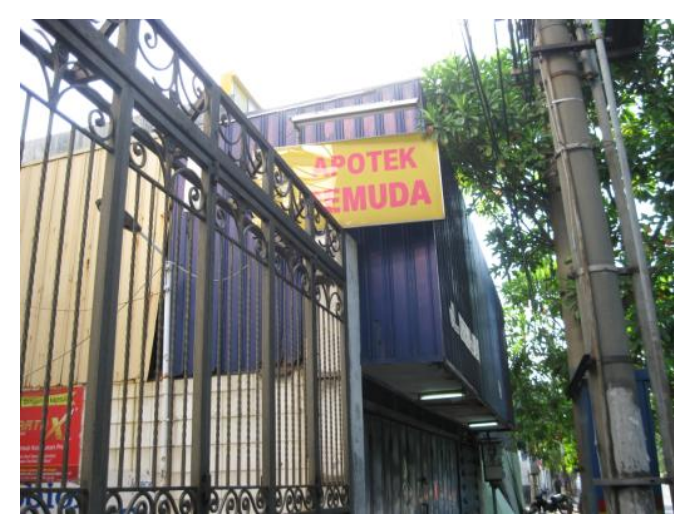

Foto 2.

Reklame yang melebihi batas Garis Sempadan Pagar.

Sumber: Survei lapangan; Agustus 2013

(2) Penyelenggaraan reklame menempel pada bangunan dapat dipasang dengan

ketentuan bidang reklame tidak melebihi Garis Sempadan Bangunan. 
Di wilayah studi terdapat dua reklame menempel bangunan yang tidak sesuai dengan pasal 20 butir (c) Peraturan Daerah Kota Surabaya No. 10 Tahun 2009 tentang Penyelenggaraan Reklame, karena dipasang melebihi GSB, yaitu reklame America Springbed Kenari Furniture dan Duta Mebel yang terletak di sisi selatan Jl. Kertajaya (lihat Foto 3).

(3) Penyelenggaraan reklame di atas bangunan diselenggarakan dengan ketentuan bidang reklame tidak boleh melebihi bidang atap tempat reklame tersebut. Kondisi lapangan menunjukkan bahwa wilayah studi terdapat 8 reklame billboard yang tidak sesuai dengan pasal 20 butir (d) Peraturan Daerah Kota Surabaya No. 10 Tahun 2009 tentang Penyelenggaraan Reklame, karena dipasang melebihi atap bangunan reklame tersebut ditempatkan.

Rinciannya adalah 2 reklame terletak di sisi Selatan sebelah Barat perempatan J1. Kertajaya-Jl. Manyar, yaitu reklame Mie Sedap dan Spjar; 3 reklame terletak di sisi selatan sebelah timur perempatan Jl. Kertajaya-Jl. Dharmawangsa, yaitu reklame Clear, Bank Jatim, dan Prima; 3 reklame terletak di sisi Selatan sebelah Barat perempatan Jl. Kertajaya-Jl. Dharmawangsa, yaitu reklame Kominfo, Kompas dan Tabungan Batara. (Foto 4).

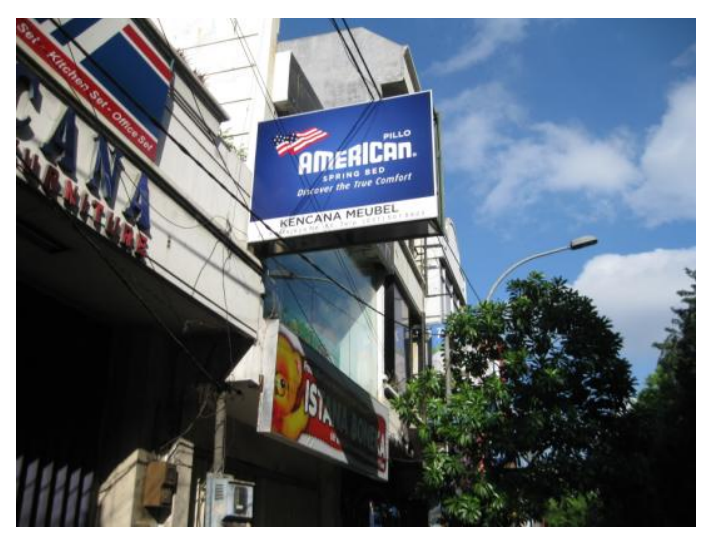

Foto 3.

Reklame pada bangunan yang melewati batas GSB.

Sumber: Survei lapangan, Agustus 2013

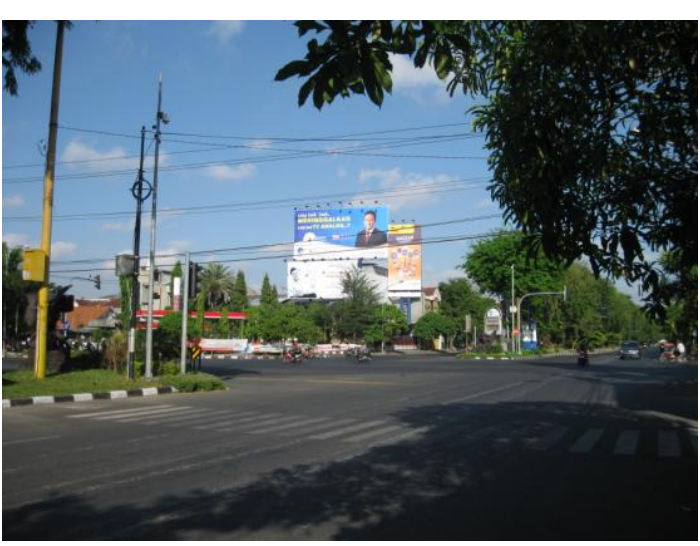

Foto 4.

Reklame yang melebihi bidang atap bangunan dimana reklame ditempatkan. Sumber: Survei lapangan, Agustus 2013 
b. Dalam pasal 29 disebutkan bahwa bangunan konstruksi reklame dilarang kosong tanpa materi.

Kondisi lapangan menunjukkan di wilayah studi terdapat satu reklame yang tidak sesuai dengan pasal 29 Peraturan Daerah Kota Surabaya No. 10 Tahun 2009 tentang Penyelenggaraan Reklame, karena kosong tanpa materi, yaitu reklame yang terletak di sisi Selatan sebelah Timur perempatan Jl. Kertajaya-Jl. Dharmawangsa (Foto 5).

\section{Kajian terhadap Peraturan Walikota Surabaya Nomor 79 Tahun 2012 tentang Tata Cara Penyelenggaraan Reklame}

a. Pada pasal 15 ayat (1) disebutkan bahwa penyelenggaraan reklame boleh dilakukan di lokasi bukan persil milik pemerintah atau yang dikuasai pemerintah. Di dalam pasal 15 ayat (2) ditegaskan bahwa penyelenggaraan reklame pada lokasi bukan persil milik pemerintah dilakukan pada titik-titik yang telah ditentukan dalam kawasan penataan reklame. Kecuali reklame videotron yang terletak pada bantaran rel kereta api, di koridor Jl. Kertajaya belum dijumpai reklame yang ditempatkan pada lokasi bukan persil seperti median, bahu jalan, trotoar, dan pulau jalan. Dalam konteks studi ini, reklame di J1. Kertajaya seluruhnya berlokasi di dalam persil.

b. Pada pasal 17 mengenai penyelenggaraan reklame di lokasi persil disebutkan bahwa:

(1) Pemasangan reklame pada tiang yang diselenggarakan pada jarak sampai dengan 6 meter dari garis pagar yang berbatasan dengan jalan hanya dibolehkan dengan ketinggian tidak melebihi ketinggian bangunan di dalam persil tersebut dan paling tinggi 9 meter dengan luas bidang tidak melebihi $24 \mathrm{~m} 2$. Kondisi lapangan menunjukkan wilayah studi terdapat 8 reklame billboard yang tidak sesuai dengan pasal 20 butir (d) Peraturan Daerah Kota Surabaya No. 10 Tahun 2009 tentang Penyelenggaraan Reklame, karena dipasang melebihi atap bangunan tempat reklame tersebut. Jaraknya hanya 0-3 meter dari garis pagar. Rinciannya adalah, 2 reklame terletak di sisi Selatan sebelah Barat perempatan J1. Kertajaya-Jl. Manyar, yaitu reklame Mie Sedap dan 
Spjar; 3 reklame terletak di sisi Selatan sebelah Timur perempatan Jl. Kertajaya-Jl. Dharmawangsa, yaitu reklame Clear, Bank Jatim, dan Prima; 3 reklame terletak di sisi Selatan sebelah Barat perempatan Jl. Kertajaya-Jl. Dharmawangsa, yaitu reklame Kominfo, Kompas, dan Tabungan Batara.

(2) Reklame yang diselenggarakan menempel pada bangunan tidak boleh melebihi bidang bangunan, dan ukuran tidak boleh melebihi $50 \%$ dari luas keseluruhan bidang bangunan yang dipergunakan untuk pemasangan reklame. Kondisi lapangan menunjukkan bahwa reklame yang dipasang pada fasade bangunan, luasnya berkisar antara 10-15\% dari luas keseluruhan bidang bangunan. Hal ini menunjukkan bahwa proporsi luasan bidang reklame pada fasade bangunan memenuhi ketentuan pasal 17 ayat (3) Peraturan Walikota Surabaya Nomor 79 Tahun 2012 tentang Tata Cara Penyelenggaraan Reklame.

(3) Persil yang berada di persimpangan dan tikungan, pemasangan reklame pada tiang yang diselenggarakan pada jarak sampai 6 meter dari garis pagar yang berbatasan dengan jalan harus memperhatikan jarak antara bidang reklame satu dengan lainnya paling sedikit 10 meter. Kondisi lapangan menunjukkan di wilayah studi terdapat 4 spot yang tidak sesuai dengan ketentuan pasal 20 ayat (7) Peraturan Walikota Surabaya Nomor 79 Tahun 2012 tentang Tata Cara Penyelenggaraan Reklame. Rinciannya adalah satu spot terletak di sisi Utara sebelah Timur perempatan Jl. Kertajaya-Jl. Dharmawangsa. Di tempat tersebut terdapat dua reklame billboard dan satu videotron yang jaraknya berdempetan; satu spot terletak di sisi Selatan sebelah Timur perempatan Jl. KertajayaJl. Dharmawangsa terdapat tiga reklame billboard yang penempatannya berdem-petan; satu spot terletak di sisi Selatan sebelah Barat perempatan Jl. Kertajaya-Jl. Dharmawangsa terdapat empat reklame billboard yang dipasang berdempetan; dan satu spot di sisi Selatan sebelah Barat perempatan J1. Kertajaya-Jl. Manyar terdapat dua reklame billboard yang dipasang berdempetan (lihat Foto 6). 


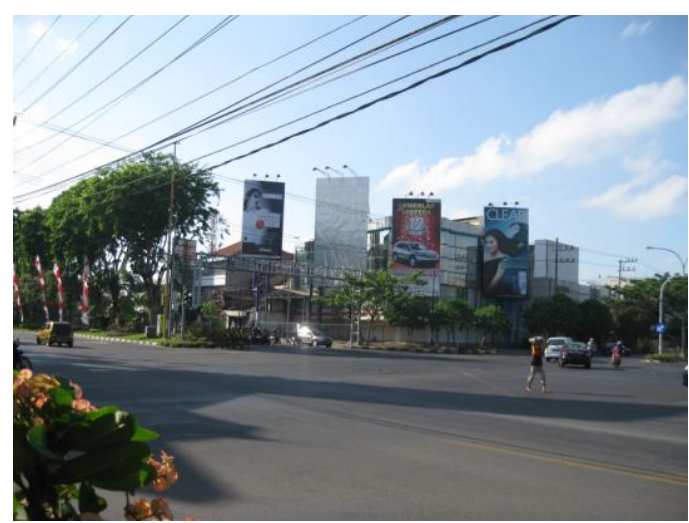

Foto 5.

Reklame tanpa materi atau reklame kosong.

Sumber : Survei lapangan Agustus 2013

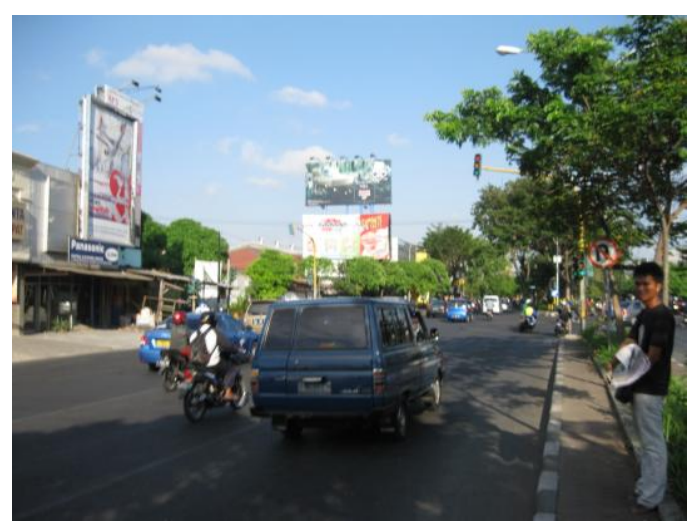

Foto 6.

Reklame dalam satu spot yang jaraknya berdempetan.

Sumber : Survei lapangan Agustus nne 1

c. Pada pasal 18 mengenai ketentuan penyelenggaraan reklame pada kawasan penataan reklame bukan persil, disebutkan:

(1) Jika reklame diselenggarakan di gardu jaga (pos polisi lalu lintas), maka:

(a) Reklame diselenggarakan secara menempel pada bangunan.

(b) Penempatan bidang reklame tidak boleh melebihi bidang bangunan dan ukuran tidak boleh melebihi 50\% dari keseluruhan bidang bangunan yang digunakan untuk pemasangna reklame.

Kondisi lapangan menunjukkan bahwa reklame yang ditempatkan di atas

Pos Polisi Lalu Lintas median Jl. Kertajaya tidak sesuai dengan ketentuan pasal 18 ayat (4), karena luas bidang reklame melebihi luas dinding pos (lebih dari 100\%). (lihat Foto 7). 


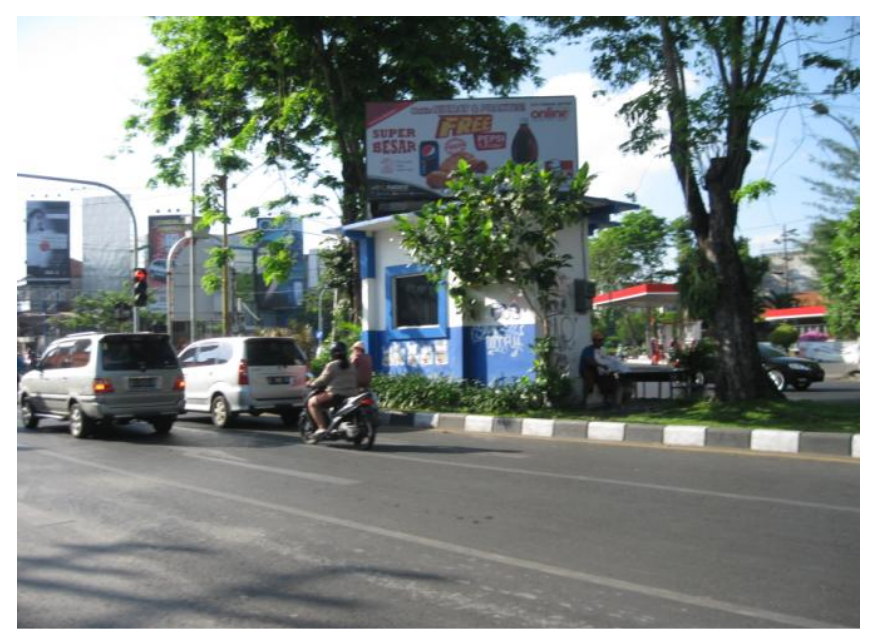

Foto 7.

Reklame yang mendominasi karena luasnya melebihi luas dinding pos polisi lalu lintas.

Sumber : Survei lapangan Agustus 2013

(2) Jika reklame diselenggarakan di bantaran rel kereta api, maka :

(a) Luas bidang reklame tidak boleh melebihi $50 \mathrm{~m} 2$.

(b) Antara titik reklame dengan titik reklame lainnya dalam satu pandangan paling sedikit 50 meter.

Ditinjau dari luasan bidang reklame, penempatan reklame di bantaran rel kereta api di sisi Barat maupun Timur viaduct tidak menyalahi ketentuan pasal 18 ayat (4) Peraturan Walikota Surabaya Nomor 79 Tahun 2012 tentang Tata Cara Penyelenggaraan Reklame.

Ditinjau dari jarak antara titik reklame dengan reklame lain dalam satu garis pandangan ke arah belakang, penempatan reklame di sisi Barat viaduct tidak menyalahi ketentuan pasal 18 ayat (4) Peraturan Walikota Surabaya Nomor 79 Tahun 2012 tentang Tata Cara Penyelenggaraan Reklame. Tetapi jika ditinjau dari jarak antara titik reklame dengan reklame lain dalam garis pandangan ke arah samping, jaraknya sangat berdekatan, tetapi hal ini tidak diatur dalam 18 ayat (4) Peraturan Walikota Surabaya Nomor 79 Tahun 2012 tentang Tata Cara Penyelenggaraan Reklame. 


\section{Kesimpulan}

1. Kajian Peraturan Pemerintah No. 56 Tahun 2009 tentang Penyelenggaraan Perkeretaapian

Walaupun pemasangan videotron pada kaki viaduct mendapat izin tertulis dari PT. (Persero) Kereta Api Indonesia DAOP VIII Surabaya, seharusnya di dalam Rumija Kereta Api terutama yang berada pada kaki viaduct, tidak digunakan untuk menempatkan reklame videotron, karena videotron tidak termasuk salah satu infrastruktur yang diizinkan sesuai pasal 59 ayat

\section{Kajian terhadap Peraturan Daerah Kota Surabaya No. 10 Tahun 2009 tentang Penyelenggaraan Reklame}

a. Terdapat 7 reklame billboard di Jl. Kertajaya yang tidak sesuai dengan pasal 20 butir (b) Peraturan Daerah Kota Surabaya No. 10 Tahun 2009 tentang Penyelenggaraan Reklame, karena dipasang melebihi GSP atau melebihi batas persil. Rinciannya 6 reklame terletak di sisi Utara Jl. Kertajaya, yaitu reklame Rumah Makan Halim, Reklame Happy Day Laundry, reklame toko, reklame Alfamart, Apotik Pemuda dan rokok Dun Hill; dan satu reklame di sisi Selatan J1. Kertajaya, yaitu reklame Polaris.

b. Terdapat satu reklame menempel bangunan yang tidak sesuai dengan pasal 20 butir (c) Peraturan Daerah Kota Surabaya No. 10 Tahun 2009 tentang Penyelenggaraan Reklame, karena dipasang melebihi GSB, yaitu reklame America Springbed Kenari Furniture yang terletak di sisi Selatan Jl. Kertajaya.

c. Terdapat 8 reklame billboard yang tidak sesuai dengan pasal 20 butir (d) Peraturan Daerah Kota Surabaya No. 10 Tahun 2009 tentang Penyelenggaraan Reklame, karena dipasang melebihi atap bangunan tempat reklame tersebut. Rinciannya, 2 reklame terletak di sisi Selatan sebelah Barat perempatan Jl. Kertajaya-Jl. Manyar, yaitu reklame Mie Sedap dan Spjar; 3 reklame terletak di sisi Selatan sebelah Timur perempatan Jl. Kertajaya-Jl. Dharmawangsa, yaitu reklame Clear, Bank Jatim, dan Prima; 3 reklame 
terletak di sisi Selatan sebelah Barat perempatan Jl. Kertajaya-Jl. Dharmawangsa, yaitu reklame Kominfo, Kompas dan Tabungan Batara.

d. Terdapat satu reklame yang tidak sesuai dengan pasal 29 Peraturan Daerah Kota Surabaya No. 10 Tahun 2009 tentang Penyelenggaraan Reklame, karena kosong tanpa materi, yaitu reklame yang terletak di sisi Selatan sebelah Timur perempatan Jl. Kertajaya-Jl. Dharmawangsa.

3. Kajian terhadap Peraturan Walikota Surabaya Nomor 79 Tahun 2012 tentang Tata Cara Penyelenggaraan Reklame

a. Terdapat 4 spot yang tidak sesuai dengan ketentuan pasal 20 ayat (7) Peraturan Walikota Surabaya Nomor 79 Tahun 2012 tentang Tata Cara Penyelenggaraan Reklame.

Rinciannya adalah satu spot terletak di sisi Utara sebelah Timur perempatan J1. Kertajaya-Jl. Dharmawangsa terdapat dua reklame billboard dan satu videotron yang jaraknya berdempetan; satu spot terletak di sisi Selatan sebelah Timur perempatan Jl. Kertajaya-Jl. Dharmawangsa terdapat tiga reklame billboard yang penempatannya berdempetan; satu spot terletak di sisi Selatan sebelah Barat perempatan Jl. Kertajaya-Jl. Dharmawangsa terdapat empat reklame billboard yang dipasang berdempetan; dan satu spot terletak di sisi Selatan sebelah Barat perempatan Jl. Kertajaya-Jl. Manyar terdapat dua reklame billboard yang dipasang berdempetan (lihat Foto 9 dan Foto 10).

b. Terdapat reklame di atas Pos Polisi Lalu Lintas median Jl. Kertajaya tidak sesuai dengan ketentuan pasal 18 ayat (4) karena luas bidang reklame melebihi luas dinding pos (lebih dari 100\%).

c. Ditinjau dari jarak antara titik reklame dengan reklame lain dalam satu garis pandangan ke arah belakang, penempatan reklame di sisi Barat viaduct tidak menyalahi ketentuan pasal 18 ayat (4) Peraturan Walikota Surabaya Nomor 79 Tahun 2012 tentang Tata Cara Penyelenggaraan Reklame. Akan tetapi, jika ditinjau dari jarak antara titik reklame dengan reklame lain dalam garis pandangan ke arah samping, jaraknya sangat berdekatan. Hal ini tidak diatur 
dalam 18 ayat (4) Peraturan Walikota Surabaya Nomor 79 Tahun 2012 tentang Tata Cara Penyelenggaraan Reklame.

\section{Daftar Pustaka}

Badan Perencanaan Pembangunan Provinsi Jawa Timur (2009). "Panduan Penataan Reklame di Koridor Jl. Ahmad Yani-Jl. Diponegoro Surabaya".

Marzuki, Peter, Mahmud, Prof. Dr. SH. MS. LLM. (2005). "Penelitian Hukum". Prenada Media Group. Jakarta.

Pemerintah Republik Indonesia (2009). "Peraturan Pemerintah Nomor 56 Tahun 2009 tentang Penyelenggaraan Perkereta-apian”.

Pemerintah Kota Surabaya (2009). "Peraturan Daerah Kota Surabaya Nomor 10 Tahun 2009 tentang Perubahan Atas Peraturan Daerah Kota Surabaya Nomor 8 Tahun 2006 Tentang Penyelenggaraan Reklame dan Pajak Reklame".

Pemerintah Kota Surabaya (2006). "Peraturan Daerah Kota Surabaya Nomor 8 Tahun 2006 tentang Penyelenggaraan Reklame dan Pajak Reklame".

Pemerintah Kota Surabaya (2012). "Peraturan Walikota Surabaya Nomor 79 Tahun 2012 tentang Tata Cara Penyelenggaraan Reklame". 